\title{
Bibliography \\ Race and medieval studies: a partial bibliography
}

\author{
Jonathan Hsy a and Julie Orlemanski \\ ${ }^{a}$ Department of English, George Washington University, Washington, DC, USA. \\ bepartment of English Language and Literature, University of Chicago, Chicago, IL, \\ USA.
}

postmedieval: a journal of medieval cultural studies (2017). 8, 500-531.

https://doi.org/10.1057/s41280-017-0072-0

The bibliography published in the following pages is the result of online collaboration and crowdsourcing of expertise. Over several months, many dozens of contributors have compiled these scholarly resources on the topics of race in the Middle Ages, race and medievalism, and race and racism in medieval studies. The spirit of the bibliography is anti-racist, critical, historical, and inclusive of minority perspectives. The version of the bibliography we print here is a snapshot, frozen in its ongoing development from crowdsourced suggestions, which have been made by contributors to a shared Google document, accessible here: goo.gl/3Yq58G. (There are plans to migrate the bibliography to a more stable online location, at which point the new address will be available at the former web link.) The first part of the bibliography we print consists of scholarly sources, ordered alphabetically by author; the second, shorter section gathers selected blog posts and journalism, also order alphabetically by author.

In introducing and printing the bibliography here, we do not claim to be its authors. We might be called its facilitators. It began on 5 June 2017, with a discussion on the 'wall' of Jonathan Hsy's Facebook profile, where he noted 
feeling 'encouraged by the sheer number of medievalists speaking out against white nationalism and racist appropriations of the medieval past in the context of recent events' - but also observed that 'people of color and religious minority perspectives on issues pertaining to medieval race, religion, language, and nation are not being cited in such work. There are many POC/ethnic/religious minority medievalists who have been thinking and publishing about such issues for quite some time and I hope, in the future, more of this scholarship will get the visibility it deserves.' In the thread of responses to Hsy's remark, Julie Orlemanski posted a one-page bibliography on 'Race and Medieval Studies' that she had prepared for a meeting of the Medieval Studies Workshop at the University of Chicago, with a link to a Google doc where anyone could edit and add to this bibliography. After ten days of anyone being able to edit the document, the settings were changed to protect it from vandalism, and contributors could suggest additions and edits, which Hsy and Orlemanski would 'approve' to incorporate into the document. Hsy has written about the context and aims of the bibliography in a post at the blog In the Middle entitled '\#MoreVoices: Citation, Inclusion, and Working Together' (http://www. inthemedievalmiddle.com/2017/06/morevoices-citation-inclusion-and.html).

Given the widely distributed and partially anonymous constitution of the 'crowd' whose suggestions generated this bibliography, we are unable to acknowledge by name all of the individuals who added to this document. However, we thank everyone who has contributed. Springer, the corporation that owns postmedieval: a journal of medieval cultural studies, has agreed to make the electronic file of the bibliography available outside of any paywall, free of charge. Our hope is that the bibliography will be re-mediated in many forms, traveling and growing as it supports new pedagogy and new scholarship. It is not lost on us that our narrative of the bibliography's origins is full of the names of for-profit corporations. Google, Facebook, and Springer all provide platforms for scholarly exchange, but they come with their own restrictions and limits. Moreover, the particular modes of sociality these platforms foster particularly, the coterie-style nature of Facebook and of medievalist communities on Twitter - influence who has seen and contributed to the bibliography to this point. The incarnation of the bibliography here will, we hope, work to broaden its accessibility. We invite all those who have sources to add or suggestions to make to visit the bibliography's online home (goo.gl/3Yq58G) and contribute to its ongoing development.

\section{Academic publications and related materials}

Abu-Lughod, Janet. Before European Hegemony: The World System A.D. 1250-1350 (Oxford: Oxford University Press, 1989). 
Ahmed, Sara. On Being Included: Racism and Diversity in Intellectual Life (Durham, NC: Duke University Press, 2012). [This is not about medieval studies specifically, but it draws from both administrative experience and philosophical/ theoretical traditions to discuss 'diversity work' in academia.]

Ahmed, Sara. 'Race as Sedimented History.' postmedieval 6.1 (2015): 94-97.

Akbari, Suzanne C. Idols in the East: European Representations of Islam and the Orient, 1100-1450 (Ithaca: Cornell University Press, 2009).

Akbari, Suzanne C. 'Placing the Jews in Late Medieval English Literature.' In Orientalism and the Jews, eds. Ivan Davidson Kalmar and Derek J. Penslar (Lebanon, NH: Brandeis University Press, 2005), 32-50.

Al-Azmeh, Aziz. 'Barbarians in Arab Eyes.' Past \& Present 134 (1992): 3-18.

Altschul, Nadia. 'Saracens and Race in Roman de la Rose Iconography: The Case of Dangier in Bodleian Douce 195.' Digital Philology 2.1 (2013): 1-15.

Ardizzone, Heidi. An Illuminated Life: Belle da Costa Green's Journey from Prejudice to Privilege (New York: Norton \& Norton, 2007).

Armstrong, Dorsey. 'Postcolonial Palomides: Malory's Saracen Knight and the Unmaking of Arthurian Community.' Exemplaria 18.1 (2006): 175-203.

Bale, Anthony. Feeling Persecuted: Christians, Jews, and Images of Violence in the Middle Ages (London: Reaktion Books, 2011).

Bale, Anthony. The Jew in the Medieval Book: English Antisemitisms 1350-1500 (Cambridge: Cambridge University Press, 2006).

Barrington, Candace. 'Dark Whiteness: Benjamin Brawley and Chaucer.' In Dark Chaucer: An Assortment, eds. Myra Seaman, Eileen Joy, and Nicola Masciandaro (Brooklyn, NY: punctum books, 2012), 1-12.

Barrington, Candace and Jonathan Hsy. 'Editors' Introduction: Chaucer's Global Orbits and Global Communities.' Literature Compass (forthcoming). [Discusses aspects of white Anglophone hegemony in Chaucer Studies and considers the ethics of appropriation and adaptation.]

Bartlett, Robert. 'Medieval and Modern Concepts of Race and Ethnicity.' Journal of Medieval and Early Modern Studies 31 (2001): 39-55. 
Bassett, Molly H., and Vincent W. Lloyd, eds. Sainthood and Race: Marked Flesh, Holy Flesh (London: Routledge, 2015).

Beckett, Katherine Scarfe. Anglo-Saxon Perceptions of the Islamic World (Cambridge: Cambridge University Press, 2003).

Bethencourt, Francisco. Racisms: from the Crusades to the Twentieth Century (Princeton: Princeton University Press, 2014).

Biller, Peter. 'Black women in medieval scientific thought.' Micrologus XIII. La pelle umana. The Human Skin (Firenze: SISMEL, 2005), 477-92.

Bindman, David and Henry Louis Gates, Jr., eds. The Image of the Black in Western Art, Volume II: From the Early Christian Era to the 'Age of Discovery.' 2 parts (Cambridge: Belknap, 2010).

Blackburn, Robin. 'The Old World Background to European Colonial Slavery.' William and Mary Quarterly 54.1 (1997): 65-102.

Blakely, Allison. Blacks in the Dutch World: The Evolution of Racial Imagery in a Modern Society (Bloomington: Indiana University Press, 2001).

Blurton, Heather and Hannah Johnson. 'Virtual Jews and Figural Criticism: Some Recent Scholarship on the Idea of the Jew in Western Culture.' Philological Quarterly 92.1 (2014): 115-30.

Brann, Ross. 'The Moors?' Medieval Encounters 15 (2009): 301-18. [Figures of the 'Moor' in medieval and early modern texts and cinema with emphasis on social agency in medieval Iberia.]

Braude, Benjamin. 'The Sons of Noah and the Construction of Ethnic and Geographical Identities in the Medieval and Early Modern Periods.' The William and Mary Quarterly 54.1 (1997): 103-42.

Brewer, Keagan. Prester John: The Legend and Its Sources (Burlington, VT: Ashgate, 2015).

Britton, Dennis Austin. 'From the Knight's Tale to The Two Noble Kinsmen: Rethinking Race, Class and Whiteness in Romance.' postmedieval 6.1 (2015): 64-78.

Burge, Amy. Representing Difference in the Medieval and Modern Orientalist Romance (Basingstoke: Palgrave, 2016). 
Calkin, Siobhain Bly. 'Marking Religion on the Body: Saracens, Categorization, and the King of Tars.' Journal of English and Germanic Philology 104.2 (2005): 219-38.

Camille, Michael. The Gargoyles of Notre-Dame: Medievalism and the Monsters of Modernity (Chicago: University of Chicago Press, 2008). [Several chapters pertain to histories of race, monstrosity, and cultural appropriation.]

Caputo, Nina and Hannah Johnson, eds. Special issue, 'The Holocaust and the Middle Ages.' postmedieval 5.3 (2014).

Cardew, Phil. “Mannfögnuður er Oss at Smjöri Pessu”: Representation of the Finns within the Icelandic Sagas.' In Text and Nation: Essays on Post-Colonial Cultural Politics, eds. Andrew Blake and and Jopi Nyman (Joensuu, Finland: Faculty of Humanities, University of Joensuu, 2001), 146-58.

Casale, Giancarlo. 'The Ethnic Composition of Ottoman Ship Crews and the "Rumi Challenge" to Portuguese Identity.' Medieval Encounters 13 (2007): $122-44$.

Caviness, Madeline. 'From the Self-Invention of the Whiteman in the Thirteenth Century to The Good, The Bad, and The Ugly.' Different Visions: A Journal of New Perspectives on Medieval Art 1 (2008): 1-33.

Cawsey, Kathy. 'Disorienting Orientalism: Finding Saracens in Strange Places in Late Medieval English Manuscripts.' Exemplaria 21.4 (2009): 380-97. [On the hybrid Viking-Saracen figure in late-medieval English works.]

Chism, Christine. 'Britain and the sea of darkness: Islandology in al-Idrisi's Nuzhat al-Mubtaq.' postmedieval 7.4 (2016): 497-510.

Chism, Christine. 'Middle-Earth, the Middle Ages, and the Aryan Nation: Myth and History in World War II.' In Tolkien the Medievalist, ed. Jane Chance (New York: Routledge, 2002), 63-92.

Christ, Georg, Saskia Dönitz, Sevket Küçükhüseyn, Daniel König, et al. Transkulturelle Verflechtungen: Mediävistische Perspektiven (Göttingen: Universitätsverlag, 2016).

Clark, Robert L.A. and Claire Sponsler. 'Othered Bodies: Racial Cross-Dressing in the Mistere de la Sainte Hostie and the Croxton Play of the Sacrament.' Journal of Medieval and Early Modern Studies 29.1 (1999): 61-87. 
Cohen, Jeffrey J., ed. Cultural Diversity in the British Middle Ages: Archipelago, Island, England (Basingstoke: Palgrave, 2008).

Cohen, Jeffrey J. 'Hybrids, Monsters, Borderlands: The Bodies of Gerald of Wales.' In The Postcolonial Middle Ages, ed. Jeffrey Jerome Cohen (New York: St. Martin's Press, 2000), 85-104.

Cohen, Jeffrey J. 'On Saracen Enjoyment: Some Fantasies of Race in Late Medieval France and England.' Journal of Medieval and Early Modern Studies 31.1 (2001): 111-44.

Cohen, Jeffrey J. 'Race.' In A Handbook of Middle English Studies, ed. Marion Turner (Chichester: Wiley Blackwell, 2013), 109-22.

Cohen, Jeffrey J. 'The Future of the Jews of York.' In Christians and Jews in Medieval England: Narratives and Contexts for the York 1190 Massacre, eds. Sarah Rees Jones and Sethina Watson (Suffolk: Boydell and Brewer, 2013), 278-93.

Cole, Richard. 'One or Several Jews? The Jewish Massed Body in Old Norse Literature.' postmedieval 5.3 (2014): 346-58.

Coppola, Manuela. 'A Tale of Two Wives: The Transnational Poetry of Patience Agbabi and Jean "Binta” Breeze.' Journal of Postcolonial Writing (2015): 305-18.

Cox, Catherine S. The Judaic Other in Dante, the Gawain Poet, and Chancer (Gainesville: University Press of Florida, 2005).

Craven, Allison. 'Esmeralda of Notre-Dame: The Gypsy in Medieval View from Hugo to Disney.' In The Disney Middle Ages: A Fairy-Tale and Fantasy Past, eds. Tison Pugh and Susan Aronstein (Basingstoke: Palgrave, 2012), 225-42.

Czarnowus, Anna. "Stille as Ston”: Oriental Deformity in the King of Tars.' Studia Anglica Posnaniensia 44 (2008): 463-74.

Dabydeen, David. 'On Not Being Milton: Nigger Talk in England Today.' In The State of Language, eds. C. Ricks and L. Michaels (Berkeley: University of California Press, 1990), 3-14.

Dagenais, John and Margaret R. Greer. 'Decolonizing the Middle Ages: Introduction.' Editors' preface to special issue, 'Decolonizing the Middle Ages,' Journal of Medieval and Early Modern Studies 30.3 (2000): 431-48. 
Davidson, Mary Catherine. Multilingualism, Multilingualism, and Chaucer (Basingstoke: Palgrave, 2010). [The study doesn't overtly discuss race but it does addresses monoglot and monocultural Anglophone perceptions of the medieval past, with reference to some important ethnic minority US scholarship.]

D'Arcens, Louise. 'Inverse Invasions: Medievalism and Colonialism in Rolf Boldrewood's A Sydneyside Saxon.' Parergon 22.2 (2005): 159-82. [This and the following two articles all deal with the ways in which medievalist discourses and practices worked to deny and displace the indigenous past in Australia.]

D'Arcens, Louise. “The last thing one might expect”: The Mediaeval Court at the 1866 Intercolonial Exhibition.' The La Trobe Journal 81 (2008): 26-39.

D'Arcens, Louise and Chris Jones. 'Excavating the Borders of Literary AngloSaxonism in Nineteenth-Century Britain and Australia.' Representations 121 (2013): 85-106.

Davis, Kathleen and Nadia Altschul, eds. Medievalisms in the Postcolonial World: The Idea of 'the Middle Ages' Outside Europe (Baltimore: Johns Hopkins University Press, 2009).

Davis-Secord, Jonathan. 'Revising Race in Layamon's Brut.' Journal of English and Germanic Philology 116 (2017): 156-81.

DeAngelo, Jeremy. 'The North and the Depiction of the Finnar in the Icelandic Sagas.' Scandinavian Studies 82 (2010): 257-86.

Devisse, Jean and Michel Mollat. The Image of the Black in Western Art (New York: William Morrow, 1979).

Dinshaw, Carolyn. 'New Approaches to Chaucer.' In Cambridge Companion to Chaucer, eds. Piero Boitani and Jill Mann (Cambridge: Cambridge University Press, 2003, repr. 2012), 270-89. [Discusses racial/religious difference and Chaucer's Man of Law's Tale in the context of post-9/11 geopolitics.]

Dinshaw, Carolyn. 'Pale Faces: Race, Religion, and Affect in Chaucer's Texts and Their Readers.' Studies in the Age of Chaucer 23 (2001): 19-41.

Dinshaw, Carolyn. 'Temporally Oriented: The Book of John Mandeville, British India, Philology, and the Postcolonial Medievalist.' Chapter 2 in Carolyn Dinshaw, How Soon is Now? Medieval Texts, Amateur Readers, and the Queerness of Time (Durham, NC: Duke University Press, 2012). 
Dor, Juliette. 'Chaucer's Viragos: A Postcolonial Engagement? A Case Study of the Man of Law's Tale, the Monk's Tale, and the Knight's Tale.' In Intersections of Gender, Religion and Ethnicity in the Middle Ages, eds. Cordelia Beattie and Kirsten A. Fenton (Basingstoke: Palgrave Macmillan, 2011), 158-82.

Ellard, Donna Beth. 'Ella's Bloody Eagle: Sharon Turner's History of the AngloSaxons and Anglo-Saxon History.' postmedieval 5.2 (2014): 215-34. [On Anglo-Saxon historiography and the traumas of British colonialism.]

Eliav-Feldon, Miriam, Benjamin Isaac, and Joseph Ziegler, eds. The Origins of Racism in the West (Cambridge: Cambridge University Press, 2009).

Epstein, Steven A. Purity Lost: Transgressing Boundaries in the Eastern Mediterranean: 1000-1400 (Baltimore: Johns Hopkins University Press, 2006).

Fabre-Vassas, Claudine. The Singular Beast: Jews, Christians, and the Pig. Trans. Carol Volk (New York: Columbia University Press, 1999).

Finke, Laurie and Martin B. Shichtman. Cinematic Illuminations: The Middle Ages on Film (Baltimore: The Johns Hopkins University Press, 2010), 195-241 [on the Crusades in film] and 180-194 [on Mel Gibson].

Finke, Laurie and Martin Shichtman. 'Exegetical History: Nazis at the Round Table.' postmedieval 5.3 (2014): 278-94.

Finke, Laurie A. and Martin B. Shichtman. 'Inner-City Chivalry in Gil Junger's Black Knight: A South Central Yankee in King Leo's Court.' In Race, Class, and Gender in 'Medieval' Cinema, ed. Tison Pugh and Lynn Ramey (New York: Palgrave, 2007), 107-121.

Finke, Laurie and Martin Shichtman. 'Paranoid History.' In King Arthur and the Myth of History (Gainesville: University Press of Florida, 2004), 186-214.

Finke, Laurie A. and Martin B. Shichtman. 'The Mont St. Michel Giant: Sexual Violence and Imperialism in the Chronicles of Wace and Layamon.' In Violence Against Women in Medieval Texts, ed. Anna Roberts (Gainesville: University Press of Florida, 1998), 56-74.

Fioravanti, Gianfranco. 'Servi, rustici, barbari: Interpretazioni medievali della Politica aristotelica.' In Annali della Scuola Normale Superiore di Pisa. Classe di Lettere e Filosofia, ser. 3.11 (1981): 399-429. [Medieval interpretations of Aristotle's theory of natural slavery, including ethnic interpretations.] 
Forni, Kathleen. 'The Canterbury Pilgrimage and African Diaspora.' Chapter 4 in Kathleen Forni, Chaucer's Afterlife: Adaptations in Recent Popular Culture (London: McFarland, 2013).

Fracchia, Carmen. 'Spanish Depictions of the Miracle of the Black Leg.' In One Leg in the Grave Revisited: The Miracle of the Transplantation of the Black Leg by the Saints Cosmas and Damian, ed. Kees W. Zimmermann (Groningen: Barkhuis, 2013), 79-91.

Fradenburg, Louise O. City, Marriage, Tournament: The Arts of Rule in Medieval Scotland (Madison: University of Michigan Press, 1991). [Ch. 13 on the motifs of the 'wild knight' and 'black lady' in heraldic pageantry]

Frakes, Jerold C., ed. Contextualizing the Muslim Other in Medieval Christian Discourse (New York: Palgrave Macmillan, 2011).

Friedman, Jamie. 'Making Whiteness Matter: The King of Tars.' postmedieval 6.1 (2015): 52-63.

Frojmovic, Eva and Catherine E. Karkov, eds. Postcolonising the Medieval Image (New York: Routledge, 2017).

Ganim, John. Medievalism and Orientalism: Three Essays on Literature, Architecture, and Cultural Identity (London: Palgrave Macmillan, 2005).

García, Antonio A. 'In the Shadow of a Mosque: Mapping the "Song of Roland."' The French Review 84.2 (December 2010): 311-25.

Gardell, Mattias. Gods of the Blood: The Pagan Revival and White Separatism (Durham: Duke University Press, 2003).

Gates, Jr., Henry Louis. Africa's Great Civilizations. Directed by Virginia Quinn and Mark Bates (PBS, 2017). DVD. [The entire series is worthwhile viewing, but episodes 2-4 are of particular interest to medievalists. Episode 2, 'The Cross and the Crescent,' focuses on the spread of Christianity and Islam into Africa between 0 and $1200 \mathrm{CE}$. Episode 3, 'Empires of Gold,' reaches 1400 or so in its exploration of the Almoravids, the Almohads, and the Empires of Mali and the Ife. Episode 4, 'Cities,' is devoted to Kilwa, Great Zimbabwe, Benin City, and Gondar and ends around 1600. Lots of detailed information can be found online at the series' PBS website.]

Giffney, Noreen. 'Monstrous Mongols.' postmedieval 3.2 (2012): 227-45. 
Giffney, Noreen. 'Que(e)rying Mongols.' Medieval Feminist Forum 36/1 (2003): 15-21.

Gillett, Andrew, ed. On Barbarian Identity (Turnhout: Brepols, 2002).

Gillett, Andrew. 'The Mirror of Jordanes: Concepts of the Barbarian, Then and Now.' In A Companion to Late Antiquity, ed. Philip Rousseau (Oxford: Blackwell, 2009), 392-408.

Gingell, Susan and Tara Chambers. 'Dubbing Chaucer and Beenie Man: Jean "Binta” Breeze's Re-Presentation of “Afrodiasporic” Women's Sexuality.' English Studies in Canada 40.4 (December 2014): 97-106.

Goldberg, David. 'The Development of the Idea of Race: Classical Paradigms and Medieval Elaborations.' International Journal of the Classical Tradition 5 (1999): 561-70.

Gow, Andrew C. The Red Jews: Antisemitism in an Apocalyptic Age, 1200-1600 (Leiden: E.J. Brill, 1995).

Gräslund, Anne-Sofie. 'How Did the Norsemen in Greenland See Themselves? Some Reflections on "Viking Identity." Journal of the North Atlantic 2.2 (2009): 131-37.

Grady, Frank. Representing Righteous Heathens in Late Medieval England (New York: Palgrave Macmillan, 2005).

Green, Monica H. 'Bodily Essences: Bodies as Categories of Difference.' In A Cultural History of the Human Body in the Middle Ages (Oxford: Berg, 2010), 149-72.

Green, Monica H. 'Conversing with the Minority: Relations among Christian, Jewish, and Muslim Women in the High Middle Ages.' Editor's Preface to special issue, 'Conversing With the Minority: Relations Among Christian, Jewish and Muslim Women in the High Middle Ages,' Journal of Medieval History 34.2 (2008): 105-18.

Green, Monica H. 'The Diversity of Human Kind.' In A Cultural History of the Human Body in the Middle Ages (Oxford: Berg, 2010), 173-90.

Green, Monica H. and Daniel Lord Smail. 'The Trial of Floreta d'Ays (1403): Jews, Christians, and Obstetrics in Later Medieval Marseille.' Journal of Medieval History 34.2 (2008): 185-211. [A summary of the story of Floreta's 
murder trial is available in 'Midwives and Obstetric Catastrophe: Retrieving the Past,' The Lancet 372, issue 9644 (September 27, 2008), 1142-43].

Grinberg, Ana. 'Robes, Turbans, and Beards: "Ethnic Passing" in Decameron X.9.' Medieval Clothing and Textiles 13 (2017): 67-81.

Grinberg, Ana. 'The Lady, the Giant, and the Land: The Monstrous in Fierabras.' eHumanista 18 (2011): 186-92.

Grinberg, Ana. '(Un)stable Identities: Impersonation, Conversion, and Relocation in Historia del emperador Carlo Magno y los doce pares.' Dissertation, University of California, San Diego, 2013.

Hahn, Thomas. 'The Difference the Middle Ages Makes: Color and Race Before the Modern World.' Journal of Medieval and Early Modern Studies 31.1(2001): $1-37$.

Haley, Shelly P. 'Be Not Afraid of the Dark: Critical Race Theory and Classical Studies.' In Prejudice and Christian Beginnings: Investigating Race, Gender, and Ethnicity in Early Christian Studies, eds. Laura Nasrallah and Elisabeth Schüssler Fiorenza (Minneapolis: Fortress Press, 2009), 27-49.

Hall, Bruce S. A History of Race in Muslim West Africa, 1600-1960 (Cambridge: Cambridge University Press, 2011).

Hall, Kim F. Things of Darkness: Economies of Race and Gender in Early Modern England (Ithaca: Cornell University Press, 1995).

Halsall, Guy. Barbarian Migrations and the Roman West, 376-568 (Cambridge: Cambridge University Press, 2007).

Hanlon, David. 'Islam and Stereotypical Discourse in Medieval Castile and Leon.' Journal of Medieval and Early Modern Studies 30.3 (2000): 479-500.

Hardy, Mat. 'Game of Tropes: The Orientalist Tradition in the Works of G.R.R. Martin.' International Journal of Arts \& Sciences 8.1 (2015): 409-20.

Harris, Stephen J. Race and Ethnicity in Anglo-Saxon Literature (London: Routledge, 2004).

Hendricks, Margo and Patricia Parker, eds. Women, 'Race,' and Writing in the Early Modern Period (London: Routledge, 1994). 
Heng, Geraldine. 'An African Saint in Medieval Europe: The Black Saint Maurice and the Enigma of Racial Sanctity.' In Sainthood and Race: Marked Flesh, Holy Flesh, eds. Molly H. Bassett and Vincent W. Lloyd (London: Routledge, 2015), 18-44.

Heng, Geraldine. Empire of Magic: Medieval Romance on the Politics of Cultural Fantasy (New York: Columbia University Press, 2004).

Heng, Geraldine. 'Holy War Redux: The Crusades, Futures of the Past, and Strategic Logic in the “Clash” of Religions.' PMLA 125.2 (2011): 422-31.

Heng, Geraldine. 'Jews, Saracens, "Black Men,” Tartars: England in a World of Difference.' In A Companion to English Literature and Culture c. 1350-c.1500, ed. Peter Brown (Oxford: Wiley-Blackwell, 2007), 247-69.

Heng, Geraldine. 'Reinventing Race, Colonizations, and Globalisms Across Deep Time: Lessons from la Longue Durée.' PMLA 130.2 (2015): 358-66.

Heng, Geraldine. 'The Invention of Race in the European Middle Ages I: Race Studies, Modernity, and the Middle Ages,' and 'The Invention of Race in the European Middle Ages II: Locations of Medieval Race,' Literature Compass 8.5 (2011): 315-50.

Herman, Gerald. 'Some Functions of Saracen Names in Old French Epic Poetry.' Romance Notes 11 (1969): 427-433.

Hess, Cordelia, and Jonathan Adams, eds. Fear and Loathing in the North: Jews and Muslims in Medieval Scandinavia and the Baltic Region (Berlin: de Gruyter, 2015).

Hoffman, Donald L. 'Assimilating Saracens: The Aliens in Malory's Morte Darthur.' Arthuriana 16.4 (2006): 43-64.

Holsinger, Bruce. 'The Color of Salvation: Desire, Death, and the Second Crusade in Bernard of Clairvaux's Sermons on the Song of Songs.' In The Tongue of the Fathers: Gender and Ideology in Twelfth-Century Latin, eds. David Townsend and Andrew Taylor (Philadelphia: University of Pennsylvania Press, 1998), 156-86.

Ho, Colleen. 'Thirteenth and Fourteenth Century European-Mongol Relations.' History Compass 10.12 (2012): 946-68. 
Hochstrasser, Julie Berger. 'Europe and the Globe, 1350-1700 - Renaissance and Reformation.' Oxford Bibliographies. DOI: https://doi/org/10.1093/OBO/ 9780195399301-0318

Hornback, Robert. 'The Folly of Racism: Enslaving Blackface and the "Natural" Fool Tradition.' Medieval and Renaissance Drama in England 20 (2007): $46-84$.

Hsy, Jonathan. Trading Tongues: Merchants, Multilingualism, and Medieval Literature (Columbus: Ohio State University Press, 2013). [Does not overtly discuss race but engages with various instances of ethnic minority US scholarship pertaining to literary voice and linguistic difference.]

Hsy, Jonathan. 'Translation Failure: The TARDIS, Cross-Temporal Language Contact, and Medieval Travel Narrative.' In The Language of Doctor Who: From Shakespeare to Alien Tongues, eds. Jason Barr and Camille D.G. Mustachio (Lanham, MD: Rowman \& Littlefield, 2014), 109-123. [Addresses intersecting facets of difference (linguistic, temporal, and racial) in popular media reinventions of medieval romance, especially of Chaucer's Man of Law's Tale.]

Hunwick, John O. and Eve Troutt Powell. The African Diaspora in the Mediterranean Lands of Islam (Princeton: Markus Wiener Publishers, 2002).

Huot, Sylvia. 'An Alien Presence: Giants as Markers of Race, Class, and Culture.' Chapter 2 in Sylvia Huot, Outsiders: The Humanity and Inhumanity of Giants in Medieval French Prose Romance (South Bend: University of Notre Dame Press, 2016).

Huot, Sylvia. 'Love, Race, and Gender in Medieval Romance: Lancelot and the Son of the Giantess.' Journal of Medieval and Early Modern Studies 37.2 (2007): 373-91.

Huot, Sylvia. Postcolonial Fictions in the Roman de Perceforest: Cultural Identities and Hybridities (Cambridge: D.S. Brewer, 2007).

Ignatiev, Noel. How the Irish Became White (New York: Routledge, 1995).

Ingham, Patricia Clare and Michelle R. Warren, eds. Postcolonial Moves: Medieval through Modern (New York: Palgrave Macmillan, 2003).

Isaac, Benjamin. 'Proto-Racism in Graeco-Roman Antiquity.' World Archaeology 38.1 (2006): 32-47. 
Iveniuk, James. 'The Seventh Signification of Sindbad: The 'Greeking' of Sindbad from the Arabian Nights to Disney.' Semiotica 189.3/4 (2012): 1-21.

Johnson, Hannah. Blood Libel: The Ritual Murder Accusation at the Limit of Jewish History (Ann Arbor: University of Michigan Press, 2012).

Johnson, Hannah. 'Massacre and Memory: Ethics and Method in Recent Scholarship on Jewish Martyrdom.' In Christians and Jews in Angevin England: The York Massacre of 1190, Narratives and Contexts, eds. Sarah Rees Jones and Sethina Watson (Rochester: Boydell and Brewer, 2013), 261-77.

Jordan, William C. 'Why "Race"?' Journal of Medieval and Early Modern Studies 31. 1 (2001): 165-73.

Kabir, Ananya Jahanara and Deanne Williams, eds. Postcolonial Approaches to the European Middle Ages: Translating Cultures (Cambridge: Cambridge University Press, 2005).

Kaplan, M. Lindsay. 'Jessica's Mother: Medieval Constructions of Jewish Race and Gender in The Merchant of Venice.' Shakespeare Quarterly 58.1 (2007): 1-30.

Kaplan, M. Lindsay. 'The Jewish Body in Black and White in Medieval and Early Modern England.' Philological Quarterly 92.1 (2013): 41-65.

Kaplan, Paul H. D. 'Black Africans in Hohenstaufen Iconography.' Gesta 26.1 (1987): 29-36.

Kaplan, Paul H.D. The Rise of the Black Magus in Western Art (Ann Arbor: UMI Research Press, 1985).

Kearney, Milo and Manuel Medrano. Medieval Culture and the Mexican American Borderlands (College Station: Texas A\&M Press, 2001).

Keita, Maghan. 'Race: What the Bookstore Hid.' In Why the Middle Ages Matter: Medieval Light on Modern Injustice, eds. Celia Chazelle, Simon Doubleday, Felice Lifshitz, and Amy G. Remensnyder (London: Routledge, 2011), 130-40.

Keita, Maghan. 'Saracens and Black Knights.' Arthuriana 16. 4 (2006): 65-77.

Kelly, Kathleen Coyne. 'The Color of Money: The BBC's “Sea Captain's Tale.” In Chaucer on Screen: Absence, Presence, and Adapting the Canterbury Tales, 
eds. Kathleen Coyne Kelly and Tison Pugh (Columbus: Ohio State University Press, 2016), 218-29.

Kennedy, Adrienne. 'Grendel and Grendel's Mother.' In The Adrienne Kennedy Reader (Minneapolis: University of Minnesota Press, 2001), 300-05. [Kennedy is an African-American playwright and she writes from her particular cultural perspective in this piece.]

Khanmohamadi, Shirin A. 'Durendal, Translated: Islamic Object Genealogies in the Chansons de Geste.' postmedieval 8.3 (2017): 321-33.

Khanmohamadi, Shirin A. In Light of Another's Word: European Ethnography in the Middle Ages (Philadelphia: University of Pennsylvania Press, 2014).

Kightley, Michael R. 'Racial Anglo-Saxonisms: From Scholarship to Fiction in England, 1850-1960.' Dissertation, University of Western Ontario, London ON, 2009.

Kightley, Michael R. 'Hereward the Dane and the English, but Not the Saxon: Kingsley's Racial Anglo-Saxonism.' Studies in Medievalism 21 (2012): 89-119.

Kightley, Michael R. 'Socialism and Translation: The Folks of William Morris's Beowulf.' Studies in Medievalism 23 (2014): 167-88.

Kim, Dorothy. Digital Whiteness and Medieval Studies (Kalamazoo: Arc Humanities Press, forthcoming).

Kim, Dorothy. 'Reframing Race and Jewish/Christian Relations in the Middle Ages.' transversal 13.1 (2015): 52-64.

Kinoshita, Sharon. 'Deprovincializing the Middle Ages.' In The Worlding Project: Doing Cultural Studies in the Era of Globalization, ed. Rob Wilson and Christopher Leigh Connery (Santa Cruz: New Pacific Press, 2007), 61-75.

Kinoshita, Sharon. Medieval Boundaries: Rethinking Difference in Old French Literature (Philadelphia: University of Pennsylvania Press, 2006).

Kinoshita, Sharon. "Pagans are wrong and Christians are right": Alterity, Gender, and Nation in the Chanson de Roland.' Journal of Medieval and Early Modern Studies 31.1 (2001): 79-111.

Kitchen, E.F. Suburban Knights: A Return to the Middle Ages (Brooklyn: PowerHouse Books, 2010). 
Kruger, Steven. 'Medieval Jewish/Christian Debate and the Question of Gender: Gilbert Crispin's Disputatio Iudei et Christiani.' In Intersections of Gender, Religion and Ethnicity in the Middle Ages, eds. Cordelia Beattie and Kirsten A. Fenton (Basingstoke: Palgrave Macmillan, 2011), 85-103.

Kruger, Steven. 'Racial/Religious and Secular Queerness in the Middle Ages.' Medieval Feminist Newsletter 16.3 (1993): 32-36.

Kruger, Steven. The Spectral Jew: Conversion and Embodiment in Medieval Europe (Minneapolis: University of Minnesota Press, 2005).

Krummel, Miriamne. Crafting Jewishness in Medieval England: Legally Absent, Virtually Present (Basingstoke: Palgrave, 2011).

Krummel, Miriamne. “'Him Jesus, That Jew!” - Representing Jewishness in the York Plays.' In Jews in Medieval Christendom: 'Slay Them Not,' eds. Merrall Llewelyn Price and Kristine T. Utterback (Leiden: Brill, 2013), 287-311.

Krummel, Miriamne. 'Staging Encounters: The Touch of the Medieval Other.' postmedieval 7.1 (2016): 147-60.

Krummel, Miriamne. 'The Pardoner, the Prioress, Sir Thopas, and the Monk: Semitic Discourse and the Jew(s).' In The Canterbury Tales, Revisited: 21stCentury Interpretations, ed. Kathleen Bishop (Newcastle upon Tyne: Cambridge Scholars, 2008), 88-110.

Krummel, Miriamne and Tison Pugh, eds. Jews in Medieval England: Teaching Representations of the Other (Basingstoke: Palgrave, 2017).

Lambert, Sarah, and Helen Nicholson, eds. Languages of Love and Hate: Conflict, Communication \& Identity in the Medieval Mediterranean (Turnhout: Brepols, 2012).

Lampert, Lisa. 'Race, Periodicity, and the (Neo-) Middle Ages.' Modern Language Quarterly 65.3 (2004): 391-421.

Lampert-Weissig, Lisa. 'Transnational Wandering Jew and the Medieval English Nation.' Literature Compass 13.12 (2016): 771-83.

Lampert-Weissig, Lisa. “'Why is This Knight Different from All Other Knights?” Jews, Anti-Semitism, and the Old French Grail Narratives.' Journal of English and Germanic Philology 106.2 (2007): 224-27. 
Lavezzo, Kathy. 'Another Country: Ælfric and the Production of English Identity.' New Medieval Literatures 3 (1999): 67-93.

Lavezzo, Kathy. 'Complex Identities: Selves and Others.' In The Oxford Handbook of Medieval English Literature, eds. Elaine Treharne and Greg Walker (Oxford: Oxford University Press, 2010), 434-57.

Lavezzo, Kathy. 'Gregory's Boys: The Homoerotic Production of English Whiteness.' In Sex and Sexuality in Anglo-Saxon England: Essays in Memory of Daniel Gillmore Calder, eds. Carol Braun Pasternack and Lisa M. C. Weston (Tempe, AZ: Arizona Center for Medieval and Renaissance Studies, 2004), 63-90.

Lavezzo, Kathy. The Accommodated Jew: English Antisemitism from Bede to Milton (Ithaca: Cornell University Press, 2016).

Lewis, Bernard. Race and Slavery in the Middle East: An Historical Enquiry (New York: Oxford University Press, 1990).

Lindow, John. 'Supernatural Others and Ethnic Others: A Millennium of World View.' Scandinavian Studies 67 (1995): 8-31.

Liu, Benjamin. Medieval Joke Poetry: The Cantigas d'Escharnho e de Mal Dizer (Harvard University Press, 2004). [Reveals cultural tensions underlying jokes about Christians, Jews, and Muslims in Iberia, including social attitudes regarding embodied difference.]

Liu, Benjamin. 'Re-Orienting Medieval Spanish Travel Narratives.' Yearbook of Comparative \& General Literature 52 (2005/2006): 19-30.

Liu, Benjamin. 'The Mongol in the Text.' In Under the Influence: Questioning the Comparative in Medieval Castile, eds. Cynthia Robinson and Leyla Rouhi (Leiden: Brill, 2005), 291-325.

Liu, Benjamin. “Un Pueblo Laborioso”: Mudejar Work in the Cantigas.' Medieval Encounters 12.3 (2006): 462-74.

Lomperis, Linda. 'Medieval Travel Writing and the Question of Race.' Journal of Medieval and Early Modern Studies 31.1 (2001): 147-64.

Loomba, Ania. 'Race and the Possibilities of Comparative Critique.' New Literary History 40.3 (2009): 501-22. 
Loomba, Ania. Shakespeare, Race, and Colonialism (Oxford: Oxford University Press, 2002).

Loomba, Ania and Jonathan Burton. Race in Early Modern England: A Documentary Companion (New York: Palgrave Macmillan, 2007). [Medieval sources included, as well as discussion of premodern race in introduction.]

Lopez-Jantzen, Nicole. 'Kings of All Italy? Overlooking Political and Cultural Boundaries in Lombard Italy.' Medieval Perspectives 29 (2014): 75-92.

MacDougall, Hugh A. Racial Myth in English History (Montreal: Harvest House, 1982).

Majid, Anouar. We Are All Moors: Ending Centuries of Crusades Against Jews and Other Minorities (Minneapolis: University of Minnesota Press, 2009). [Medieval contexts referenced throughout]

Mark, Peter. Africans in European Eyes: The Portrayal of Black Africans in Fourteenth and Fifteenth Century Europe (Syracuse: Maxwell School of Citizenship and Public Affairs, Syracuse University, 1974).

Martone, Eric. 'Treacherous "Saracens" and Integrated Muslims: The Islamic Outlaw in Robin Hood's Band and the Re-imagining of English Identity, 1800 to the Present.' Miscelánea: A Journal of English and American Studies 40 (2009): 53-76.

Mayerson, Philip. 'Anti-Black Sentiment in the Vitae Patrum.' Harvard Theological Review 71 (1978): 304-11.

Mead, Jenna. 'Reading by Said's Lantern: Orientalism and Chaucer's Treatise on the Astrolabe.' Medieval Encounters 5.3 (1999): 350-57. [Reading in light of the 'color' of the original source text attributed to a Persian Jew; the treatise is not an 'unmarked white' text.]

Mees, Bernard. 'Germanische Sturmflut: From the Old Norse Twilight to the Fascist New Dawn.' Studia Neophilologica 78 (2006): 184-98.

Mellinkoff, Ruth. Outcasts: Signs of Otherness in Northern European Art of the Late Middle Ages, 2 vols, (Berkeley: University of California Press, 1993).

Meyer, Hannah. 'Gender, Jewish Creditors, and Christian Debtors in Thirteenth-Century Exeter.' In Intersections of Gender, Religion and Ethnicity in the Middle Ages, eds. Cordelia Beattie and Kirsten A. Fenton (Basingstoke: Palgrave Macmillan, 2011), 104-24. 
Michaelis, Beatrice. 'Farbspiele in "Kudrun" und "Parzval."' In Farbe in Mittelalter. Materialität-Semantik, eds. Ingrid Bennewitz and Andrea Schindler (Berlin: Akademie-Verlag, 2011), 493-503.

Michaelis, Beatrice. 'In/Kommensurabilität. Artikulationen von "Rasse" im mittelalterlichen Nibelungenlied und in Fritz Langs Die Nibelungen.' In Durchkreuzte Helden. Das 'Nibelungenlied' und Fritz Langs 'Die Nibelungen' im Licht der Intersektionalitätsforschung, eds. Natasa Bedekovic, Andreas Kraß and Astrid Lembke (Bielefeld: transcript, 2014), 147-63.

Michaelis, Beatrice and Elahe Haschemi Yekani. 'Queering Archives of Race and Slavery - Or, on Being Wilfully Untimely and Unhappy.' In Postcoloniality - Decoloniality - Black Critique: Joints and Fissures, eds. Sabine Broeck and Carsten Junker (Frankfurt am Main/New York: Campus, 2014), 269-83.

Mielke, Andreas. Nigra sum et formosa: Afrikanerinnen in der deutschen Literatur des Mittelalters (Stuttgart: Helfant, 1992).

Mitchell-Smith, Ilan. 'The United Princesses of America: Ethnic Diversity and Cultural Purity in Disney's Medieval Past.' In The Disney Middle Ages: A FairyTale and Fantasy Past, eds. Tison Pugh and Susan Aronstein (Basingstoke: Palgrave, 2012), 209-24.

Mittman, Asa Simon. 'Are the Monstrous 'Races' Races?' postmedieval $6: 1(2015): 36-51$.

Mittman, Asa Simon. 'In those days': Giants and the Giant Moses in the Old English Illustrated Hexateuch.' In Imagining the Jew: Jewishness in AngloSaxon Literature and Culture, ed. Samantha Zacher (Ithaca: Cornell University Press, 2016), 237-63.

Mittman, Asa Simon. 'Mandeville's Jews, Colonialism, Certainty, and Art History.' In Postcolonising the Medieval Image, eds. Eva Frojmovic and Catherine Karkov (London: Ashgate, 2017).

Mittman, Asa Simon and Brantley Bryant. 'The Blemmye Speaks.' Special issue, 'Listening to Our Monsters,' Listening: Journal of Communication Ethics, Religion, and Culture (Fall 2017, forthcoming).

Mittman, Asa Simon and Marcus Hensel, eds. Classic Readings on Monster Theory: Demonstrare, 2 vols (Kalamazoo: Medieval Institute Press, WMU/ArcHumanities Press, 2018). 
Momma, Haruko. From Philology to English Studies: Language and Culture in the Nineteenth Century. (Cambridge: Cambridge University Press, 2012). [On the colonialist origins of the field.]

Momma, Haruko. 'Medievalism - Colonialism - Orientalism: Japan's Modern Identity in Natsume Soseki's Maboroshi no Tate and Kairo-ko.' In Medievalisms in the Postcolonial World: The Idea of 'the Middle Ages' Outside Europe, eds. Kathleen Davis and Nadia Altschul (Baltimore: Johns Hopkins University Press, 2009), 141-73.

Morrison, Toni. Playing in the Dark: Whiteness and the Literary Imagination (New York: Vintage, 1993). [Required reading!]

Moore, R. I. The Formation of a Persecuting Society: Power and Deviance in Western Europe, 950-1250 (Oxford: Blackwell Publishing, 1987). Expanded edition, 2007.

Mundal, Else. 'The Perception of the Saamis and their Religion in the Old Norse Sources.' In Shamanism and Northern Ecology, ed. Juha Pentikäinen (New York: Mouton de Gruyter, 1996), 97-116.

Nadhiri, Aman Y. Saracens and Franks in the 12th-15th Century European and Near Eastern Literature: Perceptions of Self and Other (London: Routledge, 2017).

Nees, Lawrence. 'Ethnic and Primitive Paradigms in the Study of Early Medieval Art.' In Paradigms and Methods in Early Medieval Studies, eds. Celia Chazelle and Felice Lifshitz (Basingstoke: Palgrave Macmillan, 2007), 41-60.

Ng, Su Fang. 'Global Souvenirs: Bridging East and West in the Malay Alexander Romance.' Literature Compass 11.7 (2014): 395-408.

$\mathrm{Ng}$, Su Fang and Kenneth Hodges. 'Saint George, Islam, and Regional Courts in Sir Gawain and the Green Knight.' Studies in the Age of Chaucer 32 (2010): 257-94.

Nirenberg, David. Communities of Violence: Persecution of Minorities in the Middle Ages, with new preface by the author (Philadelphia: University of Pennsylvania Press, 2015; orig. publ. 1996).

Nirenberg, David. 'Was there race before modernity? The example of "Jewish" blood in late medieval Spain.' In The Origins of Racism in the West, eds. Miriam Eliav-Feldon, Benjamin Isaac, and Joseph Ziegler (Cambridge: Cambridge University Press, 2009), 232-64. 
Olsen, Bjørnar. 'Belligerent Chieftains and Oppressed Hunters? Changing Conceptions of Interethnic Relationships in Northern Europe during the Iron Age and Early Medieval Period.' In Contact, Continuity, Collapse: The Norse Colonization of the North Atlantic, ed. James H. Barret (Turnhout: Brepols, 2003), 9-31.

Otaño Gracia, Nahir. 'Presenting Kin(g)ship in Medieval Irish Literature.' Enarratio: Publications of the Medieval Association of the Midwest 22 (forthcoming). [Discusses Anglo-Norman construction of the Irish.]

Otaño Gracia, Nahir. 'Vikings of the Round Table: Kingship in the Islendingasögur and the Riddarasögur.' Comitatus: A Journal of Medieval and Renaissance Studies 47 (2016): 69-101. [Discusses the addition of a Spanish Tristan to the Arthurian canon, with the second Isold becoming Isold the Dark, in the context of a protocolonial relationship between Iceland and Norway.]

Otaño Gracia, Nahir and Daniel Armenti. 'Constructing Prejudice in the Middle Ages and the Repercussions of Racism Today.' Medieval Feminist Forum (forthcoming).

Pages, Meriem. 'Robbing the Saracen to Create the Englishman: Islam and Muslims in Robin Hood: Prince of Thieves.' The Once and Future Classroom 8.2 (2010): 1-11.

Park, Katharine. 'The Meanings of Natural Diversity: Marco Polo on the "Division" of the World.' In Texts and Contexts in Medieval Science: Studies on the Occasion of John E. Murdoch's Seventieth Birthday, eds. Edith Sylla and Michael R. McVaugh (Leiden: Brill, 1997), 134-47.

Paul, Neill B., and Richard A. Sundt, eds. Special issue, 'Architecture of Colonizers/Architecture of Immigrants: Gothic in Latin America from the 16th through 20th centuries,' postmedieval 6.3 (2015).

Patton, Pamela A. 'An Ethiopian-Headed Serpent in the Cantigas de Santa María: Sin, Sex, and Color in Late Medieval Castile.' Gesta 55.2 (2016): 213-38.

Patton, Pamela A. Art of Estrangement: Redefining Jews in Reconquest Spain (State College: Penn State University Press, 2012).

Patton, Pamela A. Envisioning Others: Race, Color, and the Visual in Iberia and Latin America (Leiden and Boston: Brill, 2016). 
Phillips, Kim M. 'Warriors, Amazons, and Isles of Women: Medieval Travel Writing and Constructions of Asian Femininities'. In Intersections of Gender, Religion and Ethnicity in the Middle Ages, eds. Cordelia Beattie and Kirsten A. Fenton (Basingstoke: Palgrave Macmillan, 2011), 183-207.

Phillips, Kim M. Before Orientalism: Asian Peoples and Cultures in European Travel Writing, 1245-1510 (Philadelphia: University of Pennsylvania Press, 2013).

Ramey, Lynn T. Black Legacies: Race and the European Middle Ages (Gainesville: University Press of Florida, 2014).

Ramey, Lynn T., and Tison Pugh, eds. Race, Class, and Gender in 'Medieval' Cinema (Basingstoke: Palgrave, 2007).

Ray, Michael. 'A Black Slave on the Run in Thirteenth-Century England.' Nottingham Medieval Studies 51 (2002): 111-19.

Redworth, Glyn. 'Mythology with Attitude? A Black Christian's Defence of Negritude in Early Modern Europe.' Social History 28.1 (2003): 49-66.

Richardson, Kristina L. Gypsies in the Medieval Islamic World: The History of the Ghurabā' (London: I. B. Tauris, forthcoming).

Richardson, Kristina L. 'Blue and Green Eyes in the Islamicate Middle Ages.' Annales Islamologiques 48 (2014): 13-29.

Rowe, Nina. 'Idealization and Subjection at the South Porch of Strasbourg Cathedral.' In Beyond the Yellow Badge: Anti-Judaism and Anti-Semitism in Medieval and Early Modern Visual Culture, ed. Mitchell Merback (Leiden: Brill, 2008), 179-202.

Rowe, Nina. The Jew, the Cathedral and the Medieval City: Synagoga and Ecclesia in the Thirteenth Century (Cambridge: Cambridge University Press, 2011).

Rowe, Nina. 'Other.' Special issue, 'Medieval Art History Today - Critical Terms,' Studies in Iconography 33 (2012): 131-44.

Rowe, Nina. 'Pocket Crucifixions: Jesus, Jews and Ownership in FourteenthCentury Ivories.' Studies in Iconography 32 (2011): 81-120.

Rowe, Nina. 'Rethinking Ecclesia and Synagoga in the Thirteenth Century.' In Gothic, Art \& Thought in the Later Medieval Period: Essays in Honor of 
Willibald Sauerländer, ed. Colum Hourihane (State College: Penn State University Press, 2011), 264-91.

Rowe, Nina. 'Synagoga Tumbles, a Rider Triumphs: Clerical Viewers and the Fürstenportal of Bamberg Cathedral.' Gesta 45.1 (2006): 15-42.

Rubin, Miri. Gentile Tales: The Narrative Assault on Late Medieval Jews (New Haven: Yale University Press, 1999).

Ruggles, D. Fairchild. 'Mothers of a Hybrid Dynasty: Race, Genealogy, and Acculturation in al-Andalus.' Journal of Medieval and Early Modern Studies 34.1 (2004): 65-94.

Salvadore, Matteo. 'The Ethiopian Age of Exploration: Prester John's Discovery of Europe, 1306-1458.' Journal of World History 21.4 (2010): 593-627.

Sayers, William. 'Psychological Warfare in Vinland (Eiríks saga rauða).' In Studies in Honor of Jaan Puhvel, vol. 2, eds. John Greppin and Edgar C. Polomé (Washington, D.C.: Institute for the Study of Man, 1997), 235-64.

Scheil, Andrew P. 'Anti-Judaism in Ælfric's Lives of Saints.' Anglo Saxon England 28 (1999): 65-86.

Scheil, Andrew P. The Footsteps of Israel: Understanding Jews in Anglo-Saxon England (Ann Arbor: University of Michigan Press, 2004).

Schiff, Randy P. 'On Firm Carthaginian Ground: Ethnic Boundary Fluidity and Chaucer's Dido.' postmedieval 6.1 (2015): 23-35.

Scobie, Edward. 'The Black in Western Europe.' In African Presence in Early Europe, ed. Ivan Van Sertima (New Brunswick: Transaction Publishers, 1985), 190-202.

Segol, Marla. 'Medieval Cosmopolitanism and the Saracen-Christian Ethos.' CLCWeb: Comparative Literature and Culture 6.2 (2004).

Shichtman, Martin B. 'Wagner and the Arthurian Tradition.' In Approaches to Teaching the Arthurian Tradition, eds. Maureen Fries and Jean Watson (New York: Modern Language Association of America, 1992), 139-42.

Shichtman, Martin B. 'Whom Does the Grail Serve? Wagner, Spielberg, and the Issue of Jewish Appropriation.' In The Arthurian Revival: Essays on Form, Tradition, and Transformation, ed. Debra Mancoff (New York: Garland, 1992), 283-97. 
Sindbaek, Søren M. 'All in the Same Boat: The Vikings as European and Global Heritage.' In Heritage Reinvents Europe: Proceedings of the International Conference Ename, Belgium, 17-19 March 2011, eds. D Callebaut, Jan Mař́k, and Jana Mař́kková-Kubková (Belgium: Europae Archaeologiae Consilium, 2013), 81-88.

Snowden, Jr., Frank M. Before Colour Prejudice: The Ancient View of Blacks (Cambridge: Harvard University Press, 1983).

Snowden, Jr., Frank M. Blacks in Antiquity (Cambridge: Harvard University Press, 1970).

Snowden, Jr., Frank M. 'Some Greek and Roman Observations on the Ethiopian.' Traditio 16 (1960): 19-38.

Spicer, Andrew and Jane L. Stevens Crawshaw, eds. The Place of the Social Margins, 1350-1750 (Oxford: Routledge, 2017).

Spicer, Joaneth, ed. Revealing the African Presence in Renaissance Europe (Baltimore: Walters Art Museum, 2012). https://thewalters.org/assets/pdf/ revealing-the-african-presence-in-renaissance-europe.pdf

Spiller, Elizabeth. Reading and the History of Race in the Renaissance (Cambridge: Cambridge University Press, 2011).

Sponsler, Claire. 'Outlaw Masculinities: Drag, Blackface, and Late Medieval Laboring Class Festivities.' In Becoming Male in the Middle Ages, eds. Jeffrey Jerome Cohen and Bonnie Wheeler (New York: Garland Publishing, 1997), 321-47.

Stoessel, Jason and Reinhard Strohm. 'Voice and Song in Early Encounters between Latins, Mongols, and Persians, c.1250-c.1350.' In Towards a Global History of Music, ed. Reinhard Strohm (Abingdon: Routledge, forthcoming).

Strickland, Debra Higgs. 'Monstrosity and Race in the Late Middle Ages.' In Ashgate Research Companion to Monsters and the Monstrous, ed. Asa S. Mittman with Peter J. Dendle (Farnham: Ashgate, 2012), 365-86.

Strickland, Debra Higgs. Saracens, Demons, and Jews: Making Monsters in Medieval Art (Princeton: Princeton University Press, 2003).

Swank, Kris. 'The Arabian Nights in 21st-Century Fantasy Fiction and Film.' In Fantasy and Science-Fiction Medievalisms: From Isaac Asimov to A Game of Thrones, ed. Helen Young (Amherst: Cambria, 2015), 163-81. 
Swank, Kris. 'Black in Camelot: Race \& Ethnicity in Arthurian Legend.' Mythcon 46, Mythopoeic Society Annual Conference, 1 August 2015. Conference Paper. http://www.academia.edu/2494445/_Black_in_Camelot_Race_and_ Ethnicity_in_Arthurian_Legend_.

Swank, Kris. 'Black in Sherwood: Race \& Ethnicity in Robin Hood Legend.' 50th International Congress on Medieval Studies, 16 May 2015. https://www. academia.edu/11363597/_Black_in_Sherwood_Race_and_Ethnicity_in_Robin_ Hood_TV_and_Film_.

Sweet, James A. 'The Iberian Roots of American Racist Thought.' William and Mary Quarterly 54 (1997): 143-66.

Tavares, Elizabeth E. 'A Race to the Roof: Cosmetics and Contemporary Histories of the Elizabethan Playhouse, 1592-1596.' Shakespeare Bulletin 34, 2 (2016): 193-217. [Discusses brownface and the performance of early modern drama, with some reference to medieval traditions.]

Taylor, Julie Anne. 'Lucera Sarracenorum: A Muslim Colony in Medieval Christian Europe.' Nottingham Medieval Studies 43 (1999): 110-25.

Thomas, James M. 'The Racial Formation of Medieval Jews: A Challenge to the Field.' Ethnic and Racial Studies 30.10 (2010): 1737-55.

Thompson, Ayanna, ed. Colorblind Shakespeare: New Perspectives on Race and Performance (London: Routledge, 2006). [Various contributors; implications of race in casting and modern performance of early theater.]

Thompson, Ayanna. Performing Race and Torture on the Early Modern Stage (London: Routledge, 2008). [Medieval contexts discussed throughout.]

Thompson, Lloyd A. Romans and Blacks (Norman: University of Oklahoma Press, 1989).

Tomasch, Sylvia. 'Bibliography: Medieval Antisemitism.' Medieval Feminist Forum: A Journal of Gender and Sexuality 16.1 (1993): 38-43.

Sertima, Ivan van, ed. Golden Age of the Moor (New Brunswick: Transaction, 1992).

Verkerk, Dorothy Hoogland. 'Black Servant, Black Demon: Color Ideology in the Ashburnham Pentateuch.' Journal of Medieval and Early Modern Studies 31.1 (2001): 57-77. 
Wallace, David. 'New Chaucer Topographies.' Studies in the Age of Chaucer 29 (2007): 3-19. [Global and cross-cultural appropriations of Chaucer.]

Wallace, David. Premodern Places: Calais to Surinam, Chaucer to Aphra Benn (Oxford: Blackwell, 2004). [Discussion of genealogies of blackness and whiteness and histories of slavery.]

Walther, Hans. 'Scherz und Ernst in der Völker- und Stämme-Charakteristik mittellateinischer Verse.' Archiv für Kulturgeschichte 41 (1959): 263-301.

Warren, Michelle R. Creole Medievalism: Colonial France and Joseph Bédier's Middle Ages (Minneapolis: University of Minnesota Press, 2010).

Warren, Michelle R. "The last syllable of modernity": Chaucer in the Caribbean.' postmedieval 6.1 (2015): 79-93.

de Weever, Jacqueline. 'Introduction: The Saracen as Narrative Knot.' Editor's Preface to special issue, 'Saracens in Malory,' Arthuriana 16.4 (2006): 4-9.

de Weever, Jacqueline. Sheba's Daughters: Whitening and Demonizing the Saracen Woman in Medieval French Epic (New York: Routledge, 1998).

Whitaker, Cord J. 'Black Metaphors in the King of Tars.' Journal of English and Germanic Philology 112.2 (2013): 169-93.

Whitaker, Cord J., ed. Special issue, 'Making Race Matter in the Middle Ages,' postmedieval 6.1 (2015).

Widner, Michael. 'Samson's Touch and a Thin Red Line: Reading the Bodies of Jews and Saints in Bury St Edmunds.' Journal of English and Germanic Philology 111.3 (2012): 339-59.

Williams Boyarin, Adrienne. 'Anti-Jewish Parody around Miracles of the Virgin?: Thoughts on an Early Nonsense-Cento in Berkeley, Bancroft Library, MS UCB 92.' Notes \& Queries 54.4 (2007): 379-85.

Williams Boyarin, Adrienne. 'Desire for Religion: Mary, a Murder Libel, a Jewish Friar, and Me.' Religion and Literature 42.1-2 (2010): 23-48.

Williams Boyarin, Adrienne. 'Inscribed Bodies: The Virgin Mary, Jewish Women, and Medieval Feminine Legal Authority.' In Law and Sovereignty in the Middle Ages and Renaissance, ed. Robert S. Sturges (Turnhout: Brepols, 2011), 229-51. 
Wilsbacher, Greg. 'Lumiansky's Paradox: Ethics, Aesthetics, and Chaucer's Prioress's Tale.' College Literature 34.2 (2005): 1-28.

Wilson, Charles E., Jr. 'Medievalism, Race, and Social Order in Gloria Naylor's Bailey's Cafe.' In Medievalism and the Academy II: Cultural Studies, ed. David Metzger (Cambridge: D.S. Brewer, 1998), 74-91.

Wollenberg, Daniel. 'Defending the West: Cultural Racism and Pan-Europeanism on the Far Right.' postmedieval 5.3 (2014): 308-19.

Wollenberg, Daniel. 'The New Knighthood: Terrorism and the Medieval.' postmedieval 5.1 (2014): 21-33.

Yeager, Suzanne M. 'Racial Imagination and the Theater of War: Captivity and Execution in Richard, Coer de Lion.' In Companion to British Literature, Volume 1: Medieval Literature 700-1450, eds. Robert Demaria, Jr., Heesok Chang, and Samantha Zacher (Oxford: Wiley-Blackwell, 2014), 81-96.

Young, Helen. Constructing "England" in the Fourteenth Century: A Postcolonial Interpretation of Middle English Romance (Lewiston, NY: Edwin Mellen Press, 2010).

Young, Helen. "It's the Middle Ages, Yo!": Race, Neo/medievalism, and the World of Dragon Age,' The Year's Work in Medievalism 27 (2012): 1-9.

Young, Helen. Race and Popular Fantasy Literature: Habits of Whiteness (London: Routledge, 2016).

Young, Helen. 'Race in online fantasy fandom: whiteness on Westeros.org.' Continuum: Journal of Media \& Cultural Studies 28.5 (2014): 737-47.

Young, Helen. 'Time and Place: Medievalism and Making Race.' The Year's Work in Medievalism 28 (2013): 2-6.

Young, Helen. 'Whiteness and Time: The Once, Present, and Future Race.' In Medievalism on the Margins, ed. Karl Fulgeso with Vincent Ferre and Alicia C. Montoya, Studies in Medievalism XXIV (Cambridge: D.S. Brewer, 2015), 39-49.

Zacher, Samantha, ed. Imagining the Jew in Anglo-Saxon Literature and Culture (Toronto: University of Toronto Press, 2016).

Zacher, Samantha. Rewriting the Old Testament in Anglo-Saxon Verse: Becoming the Chosen People (London: Bloomsbury Academic, 2014). 
Ziegler, Joseph. 'Skin and Character in Medieval and Early Renaissance Physiognomy.' Micrologus XIII. La pelle umana. The Human Skin (Firenze: SISMEL, 2005), 511-35.

\section{Blog posts and journalism}

Arnarsdóttir, Eygló Svala. 'The Untold Saga of The Black Viking.' Iceland Review Online. 30 January 2015, updated 3 February 2015. http:// icelandreview.com/stuff/views/2015/01/30/untold-saga-black-viking-esa [On Bergsveinn Birgisson's novel/academic essay (Den svarte vikingen, 2013) about Geirmundur Heljarskinn ('skin like Hel' or 'black skinned') who is imagined as an immigrant of Mongolian descent.]

Barrington, Candace. 'Beyond the Anglophone Inner Circle of Chaucer Studies.' In the Middle, 11 September 2016. http://www.inthemedievalmiddle.com/2016/ 09/beyond-anglophone-inner-circle-of.html [Related: See Global Chaucers, an 'Online archive and community for post-1945, non-Anglophone Chauceriana,' https://globalchaucers.wordpress.com/]

Chaganti, Seeta, Jonathan Hsy, Sierra Lomuto, and Shokoofeh Rajabzadeh (coorganizers), with Dorothy Kim (on behalf of the Medievalists of Color). 'Whiteness in Medieval Studies: A Workshop.' 9 May 2017. http:// medievalistsofcolor.com/medievalists-of-color-/index [Note the 'about' section, the list of readings, and the link to post-workshop reflections.]

Chan, J. Clara. 'Medievalists, Recoiling from White Supremacy, Try to Diversify the Field.' Chronicle of Higher Education, 16 June 2017. http://www.chronicle. com/article/Medievalists-Recoiling-From/240666

Dockray-Miller, Mary F. 'Old English Has a Serious Image Problem.' JSTOR Daily, 3 May 2017. https://daily.jstor.org/old-english-serious-image-problem/

Fidler, Luke A. 'Teaching Medieval Art History in a Time of White Supremacy.' Material Collective, 12 August 2017. http://thematerialcollective.org/teachingmedieval-art-history-time-white-supremacy/

Green, Caitlyn. 'Two Long-Distance Migrants in the Eighth- to Tenth-century Islamic Necropolis at Tauste, Spain.' Dr. Caitlyn R. Green, 3 June 2017. http:// www.caitlingreen.org/2017/06/two-long-distance-migrants-tauste-spain.html

[Green regularly blogs on long-distance contacts and issues of racial diversity in the medieval world.] 
Hostetter, Aaron K. 'An Important Disclaimer.' Anglo-Saxon Narrative Poetry Project, Rutgers University, 19 May 2017. http://anglosaxonpoetry.camden. rutgers.edu/an-important-disclaimer/

Hsy, Jonathan. 'Native, Norse, Other: Embodied Difference and Forms of First Contact.' In the Middle, 24 September 2014. http://www.inthemedievalmiddle. com/2014/09/native-norse-other-embodied-difference.html [Discusses the 'matter of Vinland' and early North Atlantic intercultural contact in Native/ Indigenous and Euro-American cultural memory.]

Hsy, Jonathan. 'Racial Dynamics in the Medieval Literature Classroom.' What is Racial Difference?, 21 January 2016. https://blogs.wellesley.edu/ whatisracialdifference/2016/01/21/racial-dynamics-in-the-medieval-literatureclassroom/

Kao, Wan-Chuan. '\#palefacesmatter?' In the Middle, 26 July 2016. http://www. inthemedievalmiddle.com/2016/07/palefacesmatter-wan-chuan-kao.html

Kennedy, Rebecca Futo. 'Bibliography for Race and Ethnicity in the Classical World.' Classics at the Intersections, 14 August 2017. https://rfkclassics. blogspot.com/2017/08/bibliography-for-race-and-ethnicity-in.html [This bibliography is being continually updated; so far it mostly pertains to Antiquity (Greek and Roman) and Early Christian periods.]

Kim, Dorothy. 'Antifeminism, Whiteness, and Medieval Studies.' In the Middle, 16 January 2016. http://www.inthemedievalmiddle.com/2016/01/antifeminismwhiteness-and-medieval.html

Kim, Dorothy. 'Teaching Medieval Studies in a Time of White Supremacy.' In the Middle, 28 August 2017. http://www.inthemedievalmiddle.com/2017/08/ teaching-medieval-studies-in-time-of.html

Kim, Dorothy. 'The Unbearable Whiteness of Medieval Studies.' In the Middle, 10 November 2016. http://www.inthemedievalmiddle.com/2016/11/theunbearable-whiteness-of-medieval.html

L., Otto. 'Peripheries of the Middle Ages.' Medium, 28 July 2017. https:// medium.com/@vivarium/peripheries-of-the-middle-ages-558db6223488.

Livingston, Josephine. 'Racism, Medievalism, and the White Supremacists of Charlottesville.' New Republic, 15 August 2017. https://newrepublic.com/ article/144320/racism-medievalism-white-supremacists-charlottesville 
Lomuto, Sierra. 'White Nationalism and the Ethics of Medieval Studies.' In the Middle, 5 December 2016. http://www.inthemedievalmiddle.com/2016/12/ white-nationalism-and-ethics-of.html

Marian. 'The Virgin at Chartres, White Supremacy, and Medieval Studies.' Mostly Medieval: Images and Reflections, 20 September 2017. https:// mostlymedievalimagesreflections.blogspot.com/2017/09/the-virgin-at-chartreswhite-supremacy.html

Medievalists of Color (collectively authored). 'On Race and Medieval Studies: A Collective Statement by Medievalists of Color.' Medievalists of Color, 1 August 2017. http://medievalistsofcolor.com/medievalists-of-color-/on-race-and-medievalstudies.

Medievalists of Color (collectively authored). 'Statement of Solidarity With Our Jewish Colleagues.' Medievalists of Color, 7 September 2017. http:// medievalistsofcolor.com/medievalists-of-color-/statement-of-solidarity

Miyashiro, Adam. 'Decolonizing Anglo-Saxon Studies: A Response to ISAS in Honolulu.' In the Middle, 29 July 2017. http://www.inthemedievalmiddle.com/ 2017/07/decolonizing-anglo-saxon-studies.html

Peralta, Dan-el Padilla. 'Classics Beyond the Pale.' EIDOLON: a modern way to write about the ancient world, 20 February 2017. https://eidolon.pub/classicsbeyond-the-pale-534bdbb3601b [This posting (and the blog as a whole) focuses on classical antiquity but much of the content and topics are useful for medievalists as well.]

Perry, David M. 'White Supremacists Love Vikings. But They've Got History All Wrong.' The Washington Post, 31 May 2017. https://www.washingtonpost. com/posteverything/wp/2017/05/31/white-supremacists-love-vikings-buttheyve-got-history-all-wrong/

S.N., 'Medieval Memes: The Far Right's New Fascination with the Middle Ages.' The Economist, 2 January 2017. http://www.economist.com/blogs/ democracyinamerica/2017/01/medieval-memes

Steel, Karl. 'Bad Heritage, Immediacy, and Vikings.' In the Middle, 13 August 2014. http://www.inthemedievalmiddle.com/2014/08/bad-heritage-immediacyand-vikings.html [Forthcoming as 'Bad Heritage: The American Viking Fantasy, from the Nineteenth Century to Now.' In Nature, Culture, Ecologies: Nature in Transcultural Contexts, ed. Gesa Mackenthun and Stephanie Wodianka (Münster: Waxmann, 2017?)] 
Sturtevant, Paul B. 'Race, Racism, and the Middle Ages: Tearing Down the “Whites Only” Medieval World.' The Public Medievalist, 7 February 2017. http:/www.publicmedievalist.com/race-racism-middle-ages-tearing-whitesmedieval-world/ [This post is the introduction to a series by different authors on 'Race, Racism, and the Middle Ages.']

Various, 'TPM Special Series: Race, Racism and the Middle Ages.' The Public Medievalist, starting 7 February 2017. http:/www.publicmedievalist.com/raceracism-middle-ages-toc/ [See the table of contents for a series by different authors on the topic of 'Race, Racism and the Middle Ages.']

Umachandran, Mathura. 'Fragile, Handle With Care: On White Classicists.' EIDOLON: a modern way to write about the ancient world, 5 June 2017. https:/eidolon.pub/fragile-handle-with-care-66848145cf29 [This posting (and the blog as a whole) focuses on classical antiquity but much of the content and topics are useful for medievalists as well.]

Van Norden, Bryan William. 'What's With Nazis and Knights?' Huffington Post, 19 September 2017. http://www.huffingtonpost.com/entry/whats-withnazis-and-knights_us_59c0b469e4b082fd4205b98d

Waddell, Brodie. 'A Reading List of Scholarship by People of Color on Slavery and Colonialism, c.1500-1750.' The Many-Headed Monster, 25 July 2017. https://manyheadedmonster.wordpress.com/2017/07/25/a-reading-list-ofscholarship-by-people-of-colour-on-slavery-and-colonialism-c-1500-1750/ [This bibliography focuses on early modern contexts but can still be useful for understanding medieval contexts.]

Whitaker, Cord. 'Pale Like Me: Resistance, Assimilation, and "Pale Faces" Sixteen Years On.' In the Middle, 20 July 2016. http://www. inthemedievalmiddle.com/2016/07/pale-like-me-resistance-assimilation.html

Young, Helen. 'Re-making The Real Middle Ages ${ }^{\mathrm{TM}}$.' In the Middle, 21 August 2014. http://www.inthemedievalmiddle.com/2014/08/re-making-real-middleages.html 


\section{About the Authors}

Jonathan Hsy is an Associate Professor of English at George Washington University, and his publications on medieval literature, translation studies, disability theory, and digital humanities have appeared in postmedieval, PMLA, Early Modern Women Journal, and Cambridge Companion to the Body in Literature (eds. David Hillman and Ulrike Maude). He co-directs the Global Chaucers project with Candace Barrington (E-mail: jhsy@gwu.edu).

Julie Orlemanski is Assistant Professor of English at the University of Chicago. She is completing a monograph on medicine, etiology, and narrative in late-medieval England, and her new project concerns fictionality and prosopopoeia. Her work appears in Exemplaria, postmedieval, the Journal of Medieval and Early Modern Studies, Textual Practice, the Journal of English and Germanic Philology, and numerous edited collections (E-mail: julieorlemanski@uchicago.edu). 